\title{
A estabilização do arranjo corporativo e as eleições municipais de 1936 em Belo Horizonte*
}

\section{The stabilization of the corporate arrangement and the municipal election of 1936 in Belo Horizonte}

\author{
Carla Maria JUNHO ANASTASIA** \\ Programa de Pós-Graduação em História \\ Universidade Estadual de Montes Claros \\ Montes Claros (MG) \\ Brasil
}

RESUMO O artigo apresenta a estabilização do arranjo corporativo, ameaçado pela eficácia política imprevista adquirida pelo movimento sindical mineiro após a edição do decreto 19770, de março de 1931. Com o mesmo argumento de combater o comunismo, o Ministério do Trabalho interveio diretamente nos sindicatos, nomeando juntas governativas, e as forças políticas locais, em especial o Partido Progressista, buscaram arregimentar a massa trabalhadora nas eleições municipais de 1936 em Belo Horizonte.

Palavras-chave corporativismo, anti-comunismo, sindicatos

* Artigo recebido em: 15/12/2012. Aprovado em: 24/09/2013.

**Contato: carla.anastasia@terra.com.br. 
ABSTRACT The article introduces the stabilization of the corporate arrangement, threatened by the unexpected policy effectiveness acquired by the trade union of Minas Gerais after the edition of the 19770 decree, of May 1931. With the same argument of fighting the communism, the Ministry of Labor intervened directly in the trade unions, appointing governmental joints and the local political forces, especially the Progressive Party, tried to "accrete" the work force in the municipal elections of 1936 in Belo Horizonte.

Keywords corporatism, anti-communism, union trades

A intensa movimentação da sociedade civil brasileira, em 1934 e 1935, colocou em xeque a estabilidade do arranjo corporativo, implementado no imediato pós-1930. Pode-se afirmar que esta estabilidade depende fundamentalmente de o Estado romper com a autonomia e as características internas dos atores incorporados à arena pública, mantendo-os enquanto agências estatais de colaboração e de serviço. Assim, a dinâmica coercitiva que o corporativismo encerra, a priori, está baseada na necessidade de assegurar a sua forma institucional, suprimindo a expressão contínua da luta de classes nas sociedades capitalistas. ${ }^{1}$

Nos arranjos corporativos, seja de Estado ou societais, os sindicatos permanecem sindicatos - não obstante a negação reiterada deste fato pela literatura - corporificando a luta de classes, que se processa na produção. É exatamente nos momentos decisivos da militância destas entidades que a instabilidade das estruturas corporativas transparece-com a negativa da colaboração entre as classes. Nessa medida, com a continuidade histórica dos conflitos inerentes ao processo de produção capitalista, a estabilidade só pode ser mantida pela coerção. Torna-se necessário recolocar e/ou reiterar a posição dos sindicatos enquanto agências do Estado, evitando a ação autônoma das entidades.

Não obstante o avanço de algumas análises regionais sobre o processo de sindicalização oficial, ainda é corrente na literatura o entendimento de que a lei sindical, assim como a legislação trabalhista, representou uma sólida estratégia de dominação. Nessa medida, o reconhecimento de um número pouco significativo de sindicatos - ou que se pretende entender como pouco significativo - seria fruto da resistência das antigas uniões ao controle engendrado pela nova política implementada pelo Estado.

1 PANITCH, Leo. Recent theorizations of corporatism: reflections on a growth industry. British Journal of Sociology, v.31, p.159-183, 1980. 
Generalizou-se a afirmação da descaracterização e da desmobilização do movimento sindical a partir da lei de 1931, a peça mais importante do dispositivo de controle do movimento operário que, juntamente com as demais leis, teria implementado um projeto totalitário de poder do qual a expulsão de um partido dos trabalhadores e de suas organizações da vida política institucional seria o aspecto mais relevante. ${ }^{2}$ Rodrigues afirmou que o enquadramento oficial marcou, antes de mais nada, a descaracterização do sindicato que perdeu o espontaneísmo e autenticidade das primitivas organizações operárias. ${ }^{3}$ Estas tornaram-se meras fiscalizadoras e reclamadoras do cumprimento de dispositivos legais referentes ao trabalho. $\grave{A}$ descaracterização dos sindicatos como órgãos de luta operária seguir-se-ia uma mobilização controlada pelo Estado. ${ }^{4}$

Tratando da afirmação de que o sistema da legislação trabalhista constituiu-se em um instrumento de controle da mobilização, afirma Vianna que a mobilização, como entendida por Erickson, implicaria necessariamente na existência de seu contrário - um amplo processo de desmobilização. ${ }^{5}$ Nessa medida, continua Vianna, até 1935, "entre o par mobilização/desmobilização, esse último é que se reveste de caráter fundamental no trânsito para a estrutura corporativa". ${ }^{6}$ O Estado, tendo liquidado as organizações independentes, reprimido, cooptado ou corrompido seus líderes, implementou a nova política,

combinação de coerção e de manipulação do consenso através da via corporativa, facilitada em parte pela mudança na classe operária, com o recrutamento maciço de um contingente dócil à mobilização ideologizada praticada pelo Estado. $^{7}$

Ao contrário, acreditamos que a ameaça à estabilidade do arranjo corporativo que pode ser detectada em Minas Gerais decorreu da eficácia política imprevista adquirida pelo movimento sindical mineiro após a edição do Decreto 1970, de março de 1931. Esta eficácia se deveu à apropriação militante da forma política corporativa pelos sindicatos oficiais.

Sustentamos que a forma sindical corporativa, ao tornar a arena pública o conduto das demandas e reivindicações tanto da classe trabalhadora, quanto do empresariado, foi percebido por estes sindicatos mineiros como um canal eficaz de intermediação de interesses.

2 Ver TRONCA, Ítalo. Revolução de 1930: a dominação oculta. São Paulo: Brasiliense, 1986; CHAUÍ, Marilena Apontamentos para uma crítica da Ação Integralista Brasileira. In: Ideologia e mobilização popular. Rio de Janeiro: Paz e Terra, 1978; DE DECCA, Edgard. O silêncio dos vencidos. São Paulo: Brasiliense, 1981; LENHARO, Alcir. Sacralização da política. Campinas: Papirus, 1986.

3 RODRIGUES, José Albertino. Sindicato e desenvolvimento no Brasil. São Paulo: Difel, 1968

4 ERICKSON, Kenneth Paul. Sindicalismo no processo político no Brasil. São Paulo: Brasiliense, 1979.

5 VIANNA, Luiz Werneck. Liberalismo e sindicato no Brasil. Rio de Janeiro: Paz e Terra, 1976.

6 VIANNA, Luiz Werneck. Liberalismo e sindicato no Brasil, p.141.

7 VIANNA, Luiz Werneck. Liberalismo e sindicato no Brasil, p.141-142. 
Ao eleger a arena pública lócus da colocação dos conflitos que se processam na sociedade, escolha esta derivada da relação triangular característica dos arranjos corporativos, a classe trabalhadora, de certa forma, apropria-se da estrutura corporativa. Isto permite que seus conteúdos sejam transformados na dinâmica política que se processa na sociedade entre os atores. Assim, embora a forma institucional que define o corporativismo permaneça. E é esta a forma que permite à classe trabalhadora tornar a arena pública em arena de interesses, ${ }^{8}$ sua natureza e seus conteúdos são transformados. Nessa medida, a classe trabalhadora, incorporada heteronomamente ao Estado, pode desenvolver, com relação à burguesia, uma ação politicamente autônoma. ${ }^{9}$

Assim, em determinadas circunstâncias, em particular nas economias capitalistas tardias, pode ser eficaz para a ação política da classe trabalhadora, em razão da articulação triangular dos atores no arranjo corporativo, garantir a representação institucionalizada das suas organizações e buscar manter a intermediação dos conflitos, que persistem na sociedade, nas mãos do Estado.

A implantação do Estado Corporativo no Brasil, após o movimento revolucionário de 1930, alterou profundamente a dinâmica do processo de interação entre os principais atores na arena política. O Estado firmou sua posição privilegiada nesta dinâmica ao mobilizar e incorporar à vida política, por ele organizada, tanto o empresariado quanto a classe trabalhadora.

À eficácia do movimento sindical atrelado, garantida pela própria estrutura corporativa - e razão de sua instabilidade, expressa na radicalização do discurso e da ação militantes - a reação opôs - ao par da violenta repressão imposta às entidades de trabalhadores - a reiteração do formato dos sindicatos oficiais enquanto agências estatais de colaboração e serviço. Tratavase de impedir a ação autônoma dos trabalhadores no arranjo corporativo.

Ao lado da desarticulação das lideranças operárias no pós-1935, a repressão, multifacetada, facilitava a cooptação/exclusão das bases sindicais, gradativamente órfãs.

No estado de Minas Gerais, com o mesmo refrão da necessidade de se combater o comunismo, o Ministério do Trabalho interveio diretamente nos sindicatos e as forças políticas locais buscaram arregimentar a massa trabalhadora nas eleições no pós-1935. Os sindicatos oficiais, fragilizados

8 PIZZORNO, Allessandro. Introduzione allo studio della participazione política. Quaderni di Sociologia, v.15, p.235288, 1966.

9 Ver, entre outros: COHEN, Youssef. The benevolent leviathan: political conciouness among urban workers under state corporatism. The American Political Science Review, v.76, p.46-59, 1982; COLLIER, Ruth; COLLIER, David. Inducements versus constraints: disaggregating "Corporatism". The American Political Science Review, v.73, p.967-986, 1979; LUCENA, Manuel de. A Revolução Portuguesa: do desmantelamento da organização corporativa ao duvidoso fim do corporativismo. Análise Social, n.13, p.541-592, 1977; O"DONNELL, Guillermo. Corporatism and the question of the state. In: MALLOY, James M. Authoritarism and corporatism in Latin America. Pittisburg: University of Pittisburg, 1977. SCHMITTER, Philippe. Still the century of corporatism? In: PIKE,Fredrick; STRITCH, Thomas. (org.). The new corporatism. Notre Dame: University of Notre Dame, 1974. 
com a desarticulação de suas lideranças, à mercê de juntas governativas impostas, a partir dos finais de 1935 e início de 1936, pelo Ministério do Trabalho, tornaram-se, muitas vezes, presas fáceis dos mais diversos interesses.

A estabilização do arranjo corporativo, com a preservação de sua forma institucional, passava, necessariamente, pela desmobilização dos sindicatos militantes. Por sua vez, na medida em que a ordem política tornou-se mais previsível, o arranjo corporativo mais estável, cristalizou-se essa desmobilização. A partir de então, a repressão foi mais sutil, mais velada - buscou cooptar, fazer aproximar do Estado, das elites políticas, do patronato, da Igreja, as entidades de trabalhadores.

O Ministério do Trabalho, por exemplo, preocupou-se em comemorar, condignamente, o primeiro 7 de setembro após a "Intentona Comunista". Tratava-se de resgatar a "Pátria livre" na qual prevaleceriam os valores da família, da propriedade e do trabalho.

O Inspetor Regional do Ministério do Trabalho em Minas cumprindo determinação do ministro Agamenon Magalhães, convocou uma reunião de todos os sindicatos reconhecidos para preparar "com especial solenidade" o 7 de setembro.

De acordo com as instruções do Ministério, deveria ser hasteada a bandeira nacional na sede de todos os sindicatos profissionais, bem como ser proferidas conferências cívicas, "exaltando a grande data e combatendo o extremismo". ${ }^{10}$ Assim, nesse dia, caberia aos sindicatos legalmente reconhecidos o apoio direto no enfrentamento da "ameaça comunista". Na reunião, convocada pelo Inspetor Regional, estiveram presentes: o Sindicato das Profissões Liberais (patronal); o Sindicato dos Fabricantes de Tecidos (patronal); a Federação das Indústrias do Estado de Minas Gerais; o Sindicato da Força e Luz (pelego); o Sindicato dos Ferroviários da Oeste de Minas (pelego); o Sindicato Unitivo da Central do Brasil (pelego); os Sindicatos dos Empregados em Hotéis, Restaurantes e Congêneres, dos Panificadores, da Construção Civil e dos Bancários, os quatro nas mãos de juntas governativas, instaladas pelo Ministério do Trabalho; o Sindicato da Imprensa e a União dos Empregados do Comércio, ambos estritamente ligados aos interesses do patronato. ${ }^{11}$

A comissão, encarregada das solenidades, ficou constituída por um representante de sindicato patronal, um da FIEMG e dois dos sindicatos de empregados. Significativamente, foram escolhidos filiados do Sindicato dos Trabalhadores de Imprensa e da União dos Empregados do Comércio. Esta comissão deveria ficar responsável principalmente pelo controle do serviço das sociedades difusoras sobre os discursos que seriam proferidos.

10 O Dia da Pátria. Estado de Minas, Belo Horizonte, p.3, 25/08/1936.

11 O Dia da Pátria. Estado de Minas, Belo Horizonte, p.4, 27/08/1936. 
O governo de Minas cedeu, para "tão patriótico empreendimento", uma hora na Rádio Inconfidência. Deveriam ocupar seu microfone os presidentes das Juntas de Conciliação e Julgamento, o presidente da Comissão Mista de Conciliação e um representante dos sindicatos patronais. Por sua vez, os sindicatos de empregados deveriam indicar representantes para "dissertar sobre a data, o combate às ideias extremistas no país e as vantagens do atual regime que (conferia) ampla liberdade política de conformidade com a índole brasileira". ${ }^{12}$ Bem a propósito, os oradores indicados pertenciam, um deles ao Sindicato dos Ferroviários da Oeste e, os outros três, ao Sindicato dos Trabalhadores da Imprensa, ambas as entidades profundamente comprometidas com o patronato. ${ }^{13}$

No encerramento das solenidades, sessão solene no salão principal da Feira de Amostras, foram convidados para falar, em nome dos empregadores, Janot Pacheco, da FIEMG, e estranhamente, representando os empregados, o professor Magalhães Drummond.

Esta determinação em comemorar, com pompa e circunstância, o 7 de setembro, explica-se pela necessidade, após toda a "anarquia" em 1935, de conscientizar a sociedade do perigo que correra a Pátria. Tornara-se imperativo exorcizar o "vulto sinistro de Iscariote, que, agindo nas trevas (lutava) desesperadamente para vender e entregar esta grande pátria à Rússia Soviética". ${ }^{14}$

A comemoração das datas cívicas permaneceu instrumento de propaganda do governo, e a participação dos sindicatos fazia-se sempre necessária. O $1^{\circ}$ de maio de 1937, por exemplo, foi comemorado "com excepcional brilhantismo". ${ }^{15}$ Neste ano, segundo o Estado de Minas, a comemoração assumia "significação especial, porque (o país atravessava) uma crise sombria, na qual em nome do bem estar dos operários, (pretendia-se) obliterar tudo o que fora construído em quatro séculos de fatigas". ${ }^{16}$ Assim, o operariado, nesta circunstância especial, deu exemplo impressionante do sentimento da ordem e fidelidade às instituições, segundo os organizadores do evento.

Neste mesmo $1^{\circ}$ de maio, nas comemorações da data no Sindicato dos Mineiros do Morro Velho, o professor Lopes Rodrigues, convidado, comparou a pátria de cada operário a uma colmeia de abelhas. Estudou a biologia das abelhas e o sentimento dos operários, concitando os trabaIhadores de Morro Velho a amarem o Brasil como se sua colmeia fosse,

12 As solenidades cívicas de 7 de setembro. Estado de Minas, Belo Horizonte, p.4, 28/08/1936

13 A política de difundir ideias via palestras irradiadas não se restringiu às programações do Ministério do Trabalho. O Centro Leão XIII, organização cultural e de estudos sociais, que funcionava sob o controle da Confederação Católica do Trabalho, orientou palestras dirigidas às associações operárias dos diversos municípios mineiros. Confederação Católica do Trabalho. Estado de Minas, Belo Horizonte, p.5, 02/09/1937.

14 Os catholicos e o Communismo. Argus. Belo Horizonte, 11/1936.

15 O dia do Trabalho. Estado de Minas, Belo Horizonte, p.3, 01/05/1937.

16 O dia do Trabalho. Estado de Minas, Belo Horizonte, p.3, 01/05/1937. 
mostrando-Ihes a "insinceridade e os perigos das ideias estrangeiras, exóticas e dissolventes". ${ }^{17}$

Era imprescindível o concurso do operariado na luta contra os inimigos do regime.

O apoio de alguns elementos dos sindicatos oficiais à campanha contra o extremismo não era suficiente. Era preciso exercer um controle rígido sobre as entidades. Para tanto, o Ministério do Trabalho cuidou de vigiar os passos de cada uma das entidades reconhecidas.

De início, a Inspetoria Regional do Trabalho solicitou aos sindicatos uma relação atualizada do seu corpo administrativo para efeito de verificação de sua legalidade. A Inspetoria pretendia organizar um fichário completo dos sindicatos reconhecidos a fim de acompanhar o regular funcionamento dos mesmos. Cada entidade deveria, assim, informar a naturalidade, idade, estado civil, profissão, residência e lugar de trabalho de seus filiados, com a declaração, para os estrangeiros ou naturalizados, do tempo de residência no país. A relação deveria vir acompanhada de quadros especificados dos mandatos anteriores para o necessário cotejo e adoção, por parte da Inspetoria, de providências para substituir os reeleitos, caso houvesse. Além do quadro, deveria ser enviada também uma cópia dos estatutos do sindicato, aprovados pelo Ministério. ${ }^{18}$

Um mês depois, novamente voltou o Inspetor Regional aos sindicatos, solicitando que fosse enviado à Inspetoria, por estas organizações, pelas Caixas de Aposentadoria e Pensões e demais entidades trabalhistas, um exemplar de todas as publicações divulgadas em jornais e revistas. ${ }^{19}$

Contudo, exercer esse controle sobre os sindicatos, além de desempenhar suas funções rotineiras, era uma tarefa que ia além das possibilidades da Inspetoria. Em Minas, a entrada em cena do governo estadual foi a solução.

Em novembro de 1936, o governo do Estado sancionou o dispositivo, votado pela Assembleia, que autorizava o Executivo a firmar com o governo da República um convênio para execução e fiscalização das leis sociais. Para que o convênio pudesse ser implementado, seria criado um departamento - o Serviço de Organização, Assistência e Fiscalização do Trabalho - nos moldes do Departamento do Trabalho de São Paulo. A real disposição do Estado, no trabalho conjunto com a Inspetoria, traduzia-se na existência da verba, para instalação do departamento, já consignada no orçamento de 1937.

Afirmava o Inspetor Regional do Trabalho, João Fleury, ao Estado de Minas, que o quadro de auxiliares da Inspetoria era insuficiente para a

17 As comemorações do dia do Trabalho. Estado de Minas, Belo Horizonte, p.4, 05/05/1937.

18 A Inspetoria Regional do Ministério do Trabalho. Estado de Minas, Belo Horizonte, p.4, 18/11/1936

19 As entidades Trabalhistas. Estado de Minas, Belo Horizonte, p.4, 19/12/1936. 
"grande responsabilidade (do órgão) na exata observação das leis trabaIhistas". Acreditava, não obstante, que a colaboração do Estado viria suprir essa falta. ${ }^{20}$

O convênio, firmado entre o Ministério do Trabalho e o governo do Estado, inaugurava uma nova fase na qual, se, por seu lado, o Estado colaborava com o Ministério no controle das entidades, os sindicatos oficiais, por sua vez, seriam benvindos enquanto co-participantes no processo político tanto municipal, quanto estadual.

Dos operários, somente querem uma coisa: votos, para a chapa do governo ${ }^{21}$. Partidos políticos municipais são cousas graciosas, transbordantes de humorismo e avantajado motivo de chacota ${ }^{22}$.

Em 1936, aconteceram, em Belo Horizonte, eleições municipais. Ainda que, nesse artigo, não seja nosso objeto tratar da política mineira, quer estadual, quer municipal, não podemos escapar do fato de que as articulações para estas eleições envolveram os trabalhadores e alguns dos sindicatos oficiais.

A instalação de partidos políticos municipais - agremiações que pretenderam exteriorizar um caráter popular - foi uma tentativa explícita do Partido Progressista de cooptar, entre outros setores, os sindicatos de trabalhadores de Belo Horizonte.

Esta é uma análise localizada: trata somente dos sindicatos da capital. Contudo, acreditamos que possa ser importante porque apresenta, nesse processo de desmobilização das entidades de empregados, não só a montagem de interesses díspares na política estadual, tendo em vista colocar Minas numa posição mais confortável na disputa de poder ao nível federal, quanto as tentativas reiteradas de fazer os sindicatos participarem da campanha para as eleições municipais, ao lado do Partido Progressista.

Esta análise é ainda importante porque esclarece que os trabalhadores não foram, absolutamente, força considerável na aliança de interesses. Portanto, afirmações da singularidade da prática política nas eleições municipais de 1936 - via aliança com os setores emergentes - estão equivocadas. ${ }^{23}$

20 Serviço de Organização, Assistência e Fiscalização do Trabalho. Estado de Minas, Belo Horizonte, p.3, 25/11/1936.

21 Serviço de Organização, Assistência e Fiscalização do Trabalho. Estado de Minas, Belo Horizonte, p.3, 25/11/1936.

22 Serviço de Organização, Assistência e Fiscalização do Trabalho. Estado de Minas, Belo Horizonte, p.3, 25/11/1936.

23 Afirma Resende que: "No resultado eleitoral, no total de 16.027 votos válidos a FUM ficou com 56,78\%, o PRM com $28,74 \%$ e as demais agremiações com $14,48 \%$. Os resultados são significativos. De um lado, o Partido Progressista obtém maioria mediante composição com outras agremiações, o que demonstra uma prática política virtualmente diferenciada dos moldes anteriores a 30. No caso, o partido situacionista, o PP, teve que abrir espaço para as classes emergentes interessadas em participação política para obter uma vitória não tão significativa (...). Nas regras de um jogo político modificado, da década de 30, é preciso considerar que as classes sociais emergentes estão começando a pesar nos resultados eleitorais, seja por aliança, seja por posições independentes". Cf. RESENDE, Maria Efigênia Lage de. Reação oligárquica e avanço centralizador em Minas Gerais no pós-Revolução de 1930. Revista Brasileira de Estudos Políticos, Belo Horizonte, n.65, p.7-44, 1987. 
Na verdade, como veremos, a utilização de alguns setores do movimento sindical ao lado das forças políticas lideradas pelo PP só foi possível pela sua desmobilização, por meio da repressão, no pós-1935. Mesmo assim, a aliança não se concretizou. Não porque, como afirmam Faria e Grossi, os setores emergentes tenham tentado conquistar espaço para eleger seus legítimos representantes. ${ }^{24}$ Mas porque, uma vez cooptados pela Frente Única Municipal, foram dela excluídos, por pressões da Liga Eleitoral Católica, aí sim, formando a Coligação Popular Independente.

Veremos que, não obstante a presença de alguns remanescentes do movimento sindical militante, que procuraram fazer da Coligação representante legítima das classes populares, a Coligação Popular Independente foi uma alternativa circunstancial para abrigar os candidatos rejeitados pela Frente Única Municipal.

Tratando da reação oligárquica e do avanço centralizador em Minas no pós-1930, Resende aborda, no período compreendido entre 1933 e 1937, a disputa de poder entre as oligarquias mineiras. Segundo a autora, o fracasso de Arthur Bernardes em recuperar o domínio da oligarquia tradicional mineira, por meio do apoio à causa constitucional - o que lhe custou a suspensão dos direitos políticos -, e a cooptação e/ou desarticulação de outras facções oligárquicas permitiram o avanço do varguismo no Estado. ${ }^{25}$

O instrumento utilizado para a consolidação desta nova força situacionista, em oposição ao Partido Republicano Mineiro (PRM), foi o Partido Progressista, fundado em 1933, sob a presidência de Olegário Maciel e controlado, a seguir, por Benedito Valadares. Resende define o PP como "partido do interventor" - agremiação estreitamente comprometida com o governo Vargas e meramente de ocasião.

Afirma Resende que as manifestações da Aliança Nacional Libertadora, da Ação Integralista Brasileira, do movimento operário e sindical e a sucessão presidencial criaram as condições necessárias para o "Acordo Político de 36" - a união das forças políticas do estado. ${ }^{26}$

Este congraçamento foi feito, assim, em nome da necessidade de unir forças contra

24 Afirma Faria: "A dominação do Estado que, a serviço dos interesses oligárquicos, se fazia mediante um autoritarismo disfarçado às vezes em posturas paternalistas, se vestiu, agora, de uma nova roupagem que só se consolidaria mais tarde no pacto populista. Este novo estilo ficou bem evidente em 1936, quando a população belorizontina viveu sua primeira e grande experiência política, mobilizando-se frente a possibilidade de eleger o Prefeito da Capital. Em que pese a astúcia política do Prefeito em exercício no sentido de, tão cedo quanto possível, transformar várias das associações de bairros e vilas em comitês eleitorais, as pressões das organizações foram no sentido de conquistar espaço para eleger seus legítimos representantes, através de uma 'coligação popular' oposta à 'Frente Única Popular' (sic) que tinha o patrocínio político da Prefeitura". Cf. FARIA, Maria Auxiliadora; GROSSI, Yonne. Em Belo Horizonte operários vestem camisas verdes? Belo Horizonte: 1985, p.31. (mimeo).

25 RESENDE, Maria Efigênia Lage de. Reação oligárquica e avanço centralizador em Minas Gerais no pós-Revolução de 1930.

26 RESENDE, Maria Efigênia Lage de. Reação oligárquica e avanço centralizador em Minas Gerais no pós-Revolução de 1930 
a ronda dos trágicos perigos que, à esquerda, ameaçam desabar sobre nos lares, nossos templos, nossas oficinas, nossas fábricas, nossas lavouras e, à direita, sob o pretexto de atalhá-los, a dos que conspiram contra as franquias e conquistas de nossa formação democrática. ${ }^{27}$

Além do temor ao comunismo e ao integralismo, uma outra razão objetiva apontava para a unificação da política mineira - a sucessão presidencial. Buscava-se deter o varguismo, garantir a autonomia de Minas. O acordo de Benedito Valadares contava com o "apoio da facção oligárquica de Wenceslau Brás, de Carvalho de Brito (...), de representação de partidos políticos da maioria dos municípios e das agremiações, sobretudo operárias, de Belo Horizonte". ${ }^{28}$

Essas afirmações generalizantes da participação das entidades operárias no Acordo Político de 1936 são discutíveis.

É verdade que, vez ou outra, na instalação dos partidos políticos de bairros e vilas, antigas associações transformadas em comitês eleitorais, participaram do evento as novas "lideranças" dos sindicatos, surgidas a partir das juntas governativas, entronizadas nas entidades e os antigos "pelegos" do movimento sindical oficial. Por exemplo, a presença de Júlio Barbosa, representando o Sindicato Unitivo dos Ferroviários da Central, na instalação do Partido Político do Horto Florestal. ${ }^{29} \mathrm{Ou}$ o lançamento da candidatura de Francisco Martins para a Câmara Municipal, articulada pelo Sindicato dos Trabalhadores da Imprensa, entidade historicamente pelega, que foi fundada sob os auspícios do Decreto 24.694, em oposição explícita à União dos Trabalhadores do Livro e do Jornal (UTLJ), sindicato oficial militante. ${ }^{30}$

Se lideranças sindicais frequentavam, eventualmente, 5 partidos municipais, O Debate acusava o oportunismo de "pretensos líderes classistas" que passaram a frequentar, com assiduidade, os "órgãos representativos das mais autorizadas classes do trabalho". ${ }^{31}$ Referia-se o periódico à Liga Operária Mineira, "que passou o ano todo esquecida, surgiu com abundantes detalhes nas colunas dos jornais do governo, a propósito das comemorações do aniversário de sua fundação". ${ }^{32}$ Estas colunas não falavam, segundo O Debate, das necessidades dos associados da Liga Operária Mineira. Não falavam, também, das suas pretensões. Registravam tão somente o avultado número de discursos proferidos por "caçadores

\footnotetext{
27 Minas e o seu pensamento político. Discursos pronunciados na manifestação do povo de Minas a S. Excia. o Sr. Governador Benedicto Valadares por motivo do congraçamento político mineiro. Belo Horizonte: 1936.

28 RESENDE, Maria Efigênia Lage de. Reação oligárquica e avanço centralizador em Minas Gerais no pós-Revolução de 1930.

29 Instalou-se o Partido Político do Horto Florestal. Estado de Minas, Belo Horizonte, p.2, 28/01/1936.

$30 \mathrm{O} 1^{\circ}$. Candidato às próximas eleições municipais. Estado de Minas, Belo Horizonte, p.3, 10/03/1936.

31 Sindicatos e Política. O Debate, Belo Horizonte, p.2, 28/03/1936.

32 Sindicatos e Política. O Debate, Belo Horizonte, p.2, 28/03/1936.
} 
de votos (...) que em outra época jamais se abalariam ao Barro Preto para assentarem-se ao lado de homens cansados e suados, como os trabaIhadores da Liga". 33

Por outro lado, foram forjadas algumas manifestações de apoio por parte dos sindicatos. Este foi o caso da homenagem que seria prestada ao prefeito Otacílio Negrão de Lima e ao deputado Fábio Andrada pelo Sindicato dos Empregados em Hotéis, Restaurantes e Congêneres, "em atenção aos serviços que à classe têm prestado". A homenagem contaria ainda com a adesão da UTLJ, da AEC e da UEC. ${ }^{34}$

O Debate criticava acidamente o prefeito e a falácia da homenagem que lhe seria prestada:

Como cogumelos, surgem por todos bairros e vilas os famosos diretórios compostos de empregados da Prefeitura e bacharéis recém-formados. Ao mesmo tempo, esses diretórios, promovem homenagens ao administrador municipal, festas de que ninguém se apercebe, a não ser os seus promotores e pour cause..$^{35}$

Continuava o periódico afirmando que, "na sua ânsia incontida de mudar a fisionomia política da Capital", o Prefeito havia voltado os olhos para os sindicatos de operários. E "associações muito conhecidas pela sua combatividade, como o Sindicato dos Garçons e a UTLJ estariam, nem mais, nem menos, aderindo à homenagem". 36

Em abril de 1936, Getúlio Silva, antigo militante da Oposição Sindical, membro do Sindicato em Hotéis, Restaurantes e Congêneres, enviou carta a O Debate, para levar ao conhecimento público a verdade acerca da homenagem dos garçons ao Prefeito e ao deputado Fábio Andrada. Afirmava Getúlio Silva em sua carta: "Não quero aludir, senhor, a uma crônica publicada há dias, em que é oferecido um prêmio a quem descobrir um garçon entre os signatários das listas de adesão à festa ideada em nome dos humildes servidores de hotéis e restaurantes da Capital". ${ }^{37}$ Acusava o missivista que nem podia ser diferente, já que a manifestação teve como ponto de partida o Sr. Pedro Lima, "presidente perpétuo de uns tantos partidos políticos que não existem, nem existiram nunca, fora dos noticiários dos jornais". Segundo Getúlio Silva, partidos políticos municipais eram "coisas hipotéticas", sem forma definida, sem expressão real. E mais, acusava Pedro Lima de usar o Sindicato dos Empregados em Hotéis, Restaurantes e Congêneres. Afirmava: "Mas o Sr. Pedro Lima não deve apregoar que é garçon, porque

33 Sindicatos e Política. O Debate, Belo Horizonte, p.2, 28/03/1936.

34 Homenagem ao prefeito Otacílio Negrão de Lima e ao dep. Fábio Andrada. Estado de Minas, Belo Horizonte, p.4 12/01/1936.

35 O Prefeito, o deputado e os sindicatos. O Debate, Belo Horizonte, p.2, 14/011936

36 O Prefeito, o deputado e os sindicatos. O Debate, Belo Horizonte, p.2, 14/01/1936.

37 Ainda não é garçon. Uma carta a "O Debate". O Debate, Belo Horizonte, p.5, 01/04/1936. 
tal fato não é verdadeiro e causa repulsa. Poderá sê-lo ainda, se quiser. Ainda é cedo, porém...". ${ }^{38}$

Não foi diferente a indignação causada pela tentativa do Diretório Político de Ribeirão do Onça, "instituição de existência duvidosa, de mudar o nome original da localidade para "Octacílio Negrão de Lima". De acordo com o articulista de $O$ Debate:

Sabendo-se que a efêmera agremiação não passa de uma arapuca eleitoral e de sucursal do "Bureau Central de Alistamento Eleitoral", que outra coisa não é senão uma espécie de repartição do governo, para alistar eleitores de cabresto, qual a sua autoridade para tomar essa providência? ${ }^{39}$

$\mathrm{Na}$ instalação das agremiações políticas - partidos municipais - invocava-se, sempre, o operariado. Não interessava que ele estivesse presente. Tratava-se de vinculá-lo às agremiações municipais, conferindo um tom "popular" aos pretensos partidos.

Assim, na posse do Diretório Político Flamengo Conservador do Barro Preto, com a instalação do "Bureau Eleitoral dr. Abílio Machado", o homenageado, no seu discurso de agradecimento, relevava a atuação dos operários na política municipal. Não deixava porém de adverti-los "dos perigos que ameaçavam a Pátria pela insidiosa incursão de elementos exóticos, sem Deus, sem lei e sem Pátria, que (tentavam) inculcar ao país um regime inaceitável de materialismo político e social". 40

Na homenagem a Pedro Lima, oferecida pelo Partido Político das Vilas Reunidas Além Gameleira, o vice-presidente do partido, em discurso, elogiava a formação de uma frente única na capital, para disputar as eleições municipais. Dizia o orador:

Nós temos a grata esperança de que a Comissão dos 15, da Frente Única Municipal, indicará o vosso nome (Pedro Lima) para ocupar uma cadeira na Câmara Municipal (...) O amigo dos operários, em todas as ocasiões, há de vencer, para no legislativo municipal continuar a defender os nossos direitos e procurar nos auxiliar, como sempre tem feito. ${ }^{41}$

Em seu discurso, agradecendo a homenagem, Pedro Lima repudiou "os credos dissolventes das sociedades contemporâneas", exaltando a liberaldemocracia. Finalmente, concitou o operariado a se colocar ao lado dos governantes a fim de que estes pudessem "subjugar a onda de subversão que (ameaçava) as nossas instituições". ${ }^{42}$

38 Ainda não é garçon. Uma carta a "O Debate". O Debate, Belo Horizonte, p.5, 01/04/1936.

39 O povo de Ribeirão do Onça... O Debate, Belo Horizonte, p.3, 24/03/1936.

40 Política dos Bairros. Estado de Minas, Belo Horizonte, p.5, 17/03/1936.

41 Frente Única Municipal. Estado de Minas, Belo Horizonte, p.4, 5/05/1936.

42 Frente Única Municipal. Estado de Minas, Belo Horizonte, p.4, 5/05/1936. 
Fica explícito, na fala dos políticos ligados à Frente Única Municipal, o discurso anti-comunista que acompanhou, sistematicamente, no pós1935, todas as referências ao operariado. Contudo, toda essa campanha, que pretendeu vincular o Partido Progressista, os partidos municipais e os sindicatos de trabalhadores, foi em vão. A aliança, tão comentada, não se realizou.

Em maio de 1936, na apresentação da chapa da Frente Única Municipal, que concorreria ao pleito municipal, constatou-se, com perplexidade, que não constavam da mesma os nomes dos representantes dos operários, dos comerciários e dos esportistas. Haviam sido feitas modificações de última hora, sob pressão da Liga Eleitoral Católica. ${ }^{43}$

Para resolver este problema, foi criada a Coligação Popular Independente. Mauro Queiroz, presidente do Centro dos Chauffeurs, em manifesto aos amigos e ao eleitorado independente, explicava que, surpreendido com a recusa de seu nome pela Liga Eleitoral Católica, recusa confirmada pelas ordens transmitidas aos diretórios políticos dos bairros da Capital para que o mesmo fosse sumariamente cancelado das listas em que se encontrava, aceitava a indicação de sua candidatura pela Coligação Popular Independente. ${ }^{44}$

\section{Considerava Mário Queiroz}

a opinião da LEC inoportuna, insincera e sobretudo prejudicial, não só aos destinos políticos do país mas à própria Igreja Católica e atendendo a um grupo de amigos chauffeurs, espíritas e protestantes e alguns católicos de consciências livres, (via-se) na contingência de aceitar a candidatura, menos pelo desejo de vitória do que de demonstração de independência do eleitorado da Capital, que não pode deixar de reprovar a atitude da referida Liga. ${ }^{45}$

O manifesto da Coligação Popular Independente partia da constatação de que a Câmara Municipal devia ser um resumo das tendências e aspirações de todas as classes. Contudo, as chapas da Frente Única Municipal e do PRM não haviam levado em conta "essa exigência da soberania popular". Esses partidos não haviam contemplado os operários, os comerciários, os esportistas, os condutores, os motorneiros, os chauffeurs etc. Isto porque haviam sucumbido às pressões do clero, especialmente da LEC e não incluíram nas suas chapas os representantes do trabalho. Para abrigá-los foi criada a Coligação Popular Independente que tinha um programa singelo: servir honesta e lealmente o povo de Belo Horizonte. ${ }^{46}$

43 A chapa do Partido Progressista para as eleições na Capital. Estado de Minas, Belo Horizonte, p.10, 27/05/1936.

44 Coligação Popular Independente. Estado de Minas, Belo Horizonte, p.12, 28/05/1936.

45 Coligação Popular Independente.

46 Coligação Popular Independente. Manifesto. Estado de Minas, Belo Horizonte, p.10, 30/05/1936. 
A chapa da Coligação foi formada por: Francisco Martins, do Sindicato dos Trabalhadores da Imprensa; Caetano Guimarães, corretor; Mauro Queiroz, do Centro dos Chauffeurs; Ibrahim Augusto Teixeira, presidente do Sindicato dos Empregados em Hotéis, Restaurantes e Congêneres; e David de Almeida, do Sindicato da Construção Civil, que teve seu nome substituído por não ter regularizado seu título de eleitor. Coincidentemente, era o único candidato que havia militado no movimento sindical oficial combativo no pré-1935, tendo inclusive sido indiciado em processo do Tribunal de Segurança Nacional. Em seu lugar, ficou Bento Teixeira, estucador.

As comemorações do registro da legenda da Coligação Popular Independente foram realizadas na sede do Sindicato de Empregados em Hotéis, Restaurantes e Congêneres. Entre os diversos discursos proferidos na festa, destacaram-se os de Gentil Noronha, que criticou o integralismo, e o de Manoel Paulino, ambos antigos militantes da combativa UTLJ.

Segundo Manoel Paulino, as comemorações do registro da legenda da Coligação Popular Independente significavam a reação dos trabalhadores contra os políticos profissionais. Dizia:

Admirável a coragem dos operários, organizando uma chapa de elementos de sua classe para disputar as eleições com os eternos políticos profissionais. De um lado, concorrendo com os trabalhadores, vemos esses profiteurs, e de outros integralistas. Ambos, às vésperas do pleito, intitulam-se amigos dos operários e solicitam a estes votarem neles. É a eterna comédia das amizades de véspera! Eles se apresentam nos bailes humildes para dançarem, vão passear na Pedreira (...) Deixa de ser cinismo para ser insulto! ${ }^{47}$

A Coligação foi considerada como uma primeira reação ao integralismo e um protesto contra alguns elementos que se diziam defensores da Igreja Católica.

Explicava-se, na festa, o veto às candidaturas populares tanto na chapa da Frente Única Municipal quanto do PRM. Segundo o candidato Francisco Martins, além de problemas da Prefeitura na desapropriação de terrenos pertencentes à Igreja de Lourdes, aproximava-se o Congresso Eucarístico, que seria "largamente subvencionado pelos cofres da Prefeitura". Daí, o repúdio aos nomes dos trabalhadores. ${ }^{48}$

A Coligação Popular Independente ficou em penúltimo lugar nas eleições municipais de 1936. A Frente Única Municipal foi, disparada, a campeã. Se a vitória do Partido Progressista deu a entender a Benedito Valadares o êxito de suas articulações, com o Acordo Político de 1936, o

47 Homenageados os candidatos da Coligação Popular Independente. Estado de Minas, Belo Horizonte, p.3, 03/06/1936.

48 Homenageados os candidatos da Coligação Popular Independente. Estado de Minas, Belo Horizonte, p.3, 03/06/1936. 
grande articulador do projeto foi Getúlio Vargas. A unificação política de Minas, na verdade, constituiu

uma estratégia que refletia a política de Vargas destinada a unificar as forças eleitorais para se necessário às oposições de São Paulo com Armando Sales de Oliveira e do Rio Grande do Sul com Flores da Cunha. Num sentido mais amplo a unificação da política de Minas criava a retaguarda necessária ao Golpe de 37.49

Se Vargas foi o grande vencedor na articulação das forças políticas que garantiram o golpe de 1937, também o foi na consolidação da estabilidade do arranjo corporativo e, por consequência, na preservação de sua forma institucional.

Os sindicatos oficiais, cada vez mais controlados, assumiram, gradativamente, a feição de agências estatais de colaboração e serviço. ${ }^{50}$

Com o Decreto 1.402, de 5 de agosto de 1939, retornou-se à unicidade sindical, interrompida pelo Decreto 24.694, de 1934, e foram determinados papéis específicos para as organizações tais como a criação de cooperativas de crédito e consumo, de escolas, assistência médica etc.

No ano de 1940, procederam-se às necessárias adaptações ao novo regime legal permanecendo paralisadas as entidades que passaram do regime de pluralidade sindical para o de unicidade. O incremento do número de sindicatos oficiais em 1941 está ligado à edição do Decreto-lei 2.377, de 1940, que criou o imposto sindical, e à vigorosa campanha desencadeada por Vargas em favor de uma sindicalização massiva.

49 RESENDE, Maria Efigênia Lage de. Reação oligárquica e avanço centralizador em Minas Gerais no pós-Revolução de 1930.

50 Em Minas, em janeiro de 1939, foi fundada a União dos Sindicatos de Empregados de Belo Horizonte, que ilustra bem nossa afirmação. Segundo o Estado de Minas, este era um assunto que interessava de perto a todos os sindicatos pois significava "mais uma etapa na organização das classes profissionais dentro de agremiações oficiais e auxiliares do poder público". Continuava: "Vem a ideia de encontro ao espírito do regime, que doutrina a corporificação de todos os obreiros em organizações representativas de suas classes para, de modo mais fácil e eficiente, dirimir e resolver as questões trabalhistas e mais eficientemente colaborar com os poderes públicos". Será fundada a União dos Sindicatos de Empregados da Capital. Estado de Minas, Belo Horizonte, p.2, 13/01/1939. Ver também: Vai ser fundada a União Geral dos Sindicatos. Estado de Minas, Belo Horizonte, p.2, 14/01/1939; Fundada a União dos Sindicatos de Empregados de Belo Horizonte. Estado de Minas, Belo Horizonte, p.3, 21/01/1939. 